\title{
Biology and Management of Poison Ivy (Toxicodendron radicans) in the Home Landscape ${ }^{1}$
}

\section{Yuvraj Khamare and Chris Marble ${ }^{2}$}

\section{Introduction}

Poison ivy (Toxicodendron radicans) is an allergenic plant of the cashew family native to North America. Poison ivy and the closely related plants poison oak (Toxicodendron toxicarium) and poison sumac (Toxicodendron vernix) all grow in Florida and contain the oily resin called urushiol. A guide to identification of these species is available in the article Identification of Poison Ivy, Poison Oak, Poison Sumac, and Poison Wood. This EDIS publication is intended to aid landowners, gardeners, horticulturalists, and pest management professionals in identification and management of poison ivy in residential and commercial landscapes.

\section{Species Description}

\section{Class}

Dicotyledon

\section{Family}

Anacardiaceae (Cashew family)

\section{Other common names}

Eastern poison ivy

\section{Life Span}

Perennial growing vine or woody shrub

\section{Habitat}

Poison ivy is native to Florida and grows best in fertile, moist, and well-drained soil. It is often found in fields, pastures, farms, home landscapes, and woodland areas. As a vine, it can climb along fences and buildings, or it may attach itself to shrubs, trees, or other structures (Figure 1).

\section{Distribution}

Poison ivy is native to North America, found from Maine to Florida and westward from Nebraska to Texas (USDANRCS 2019). It is widely distributed through all the counties in Florida (Wunderlin et al. 2019). It can also be found throughout southern Canada, Mexico, Japan, and central China.

1. This document is ENH1345, one of a series of the Environmental Horticulture Department, UF/IFAS Extension. Original publication date July 2021. Visit the EDIS website at https://edis.ifas.ufl.edu for the currently supported version of this publication.

2. Yuvraj Khamare, graduate research assistant; and Chris Marble, associate professor, Environmental Horticulture Department, UF/IFAS Mid-Florida Research and Education Center, Apopka, FL 32703.

The use of trade names in this publication is solely for the purpose of providing specific information. UF/IFAS does not guarantee or warranty the products named, and references to them in this publication do not signify our approval to the exclusion of other products of suitable composition.

Use pesticides safely. Read and follow directions on the manufacturer's label.

The Institute of Food and Agricultural Sciences (IFAS) is an Equal Opportunity Institution authorized to provide research, educational information and other services only to individuals and institutions that function with non-discrimination with respect to race, creed, color, religion, age, disability, sex, sexual orientation, marital status, national origin, political opinions or affiliations. For more information on obtaining other UF/IFAS Extension publications, contact your county's UF/IFAS Extension office. U.S. Department of Agriculture, UF/IFAS Extension Service, University of Florida, IFAS, Florida A \& M University Cooperative Extension Program, and Boards of County Commissioners Cooperating. Nick T. Place, dean for UF/IFAS Extension. 


\section{Growth Habit}

Poison ivy can grow as a woody shrub or an erect vine that climbs on trees, fences, and walls with the help of its aerial roots (Figure 1).

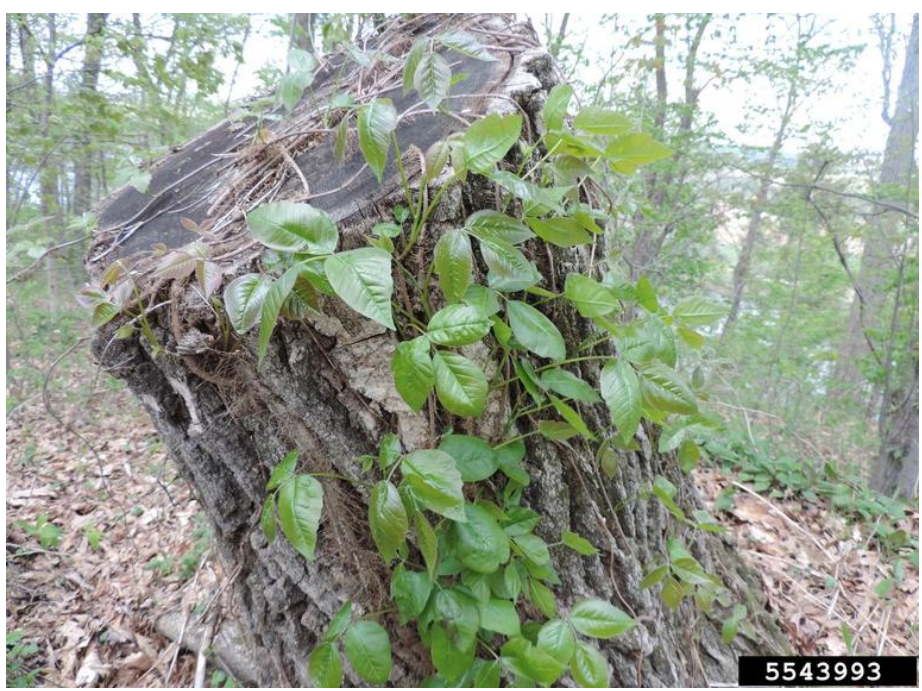

Figure 1. Poison ivy vine climbing a tree.

Credits: Richard Gardner, Bugwood.org

\section{Seedling}

Seedlings first emerge with 2 cotyledon leaves, with 3 parted leaves appearing next. The cotyledon is light green with narrow, oblong-shaped leaves (Figure 2).

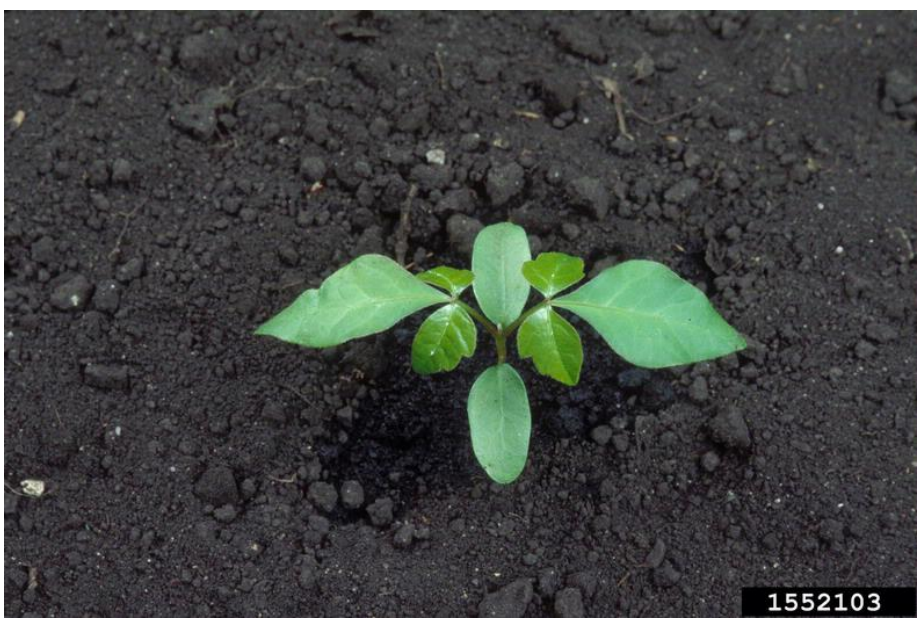

Figure 2. Poison ivy seedling.

Credits: Ohio State Weed Lab, The Ohio State University, Bugwood.org

\section{Shoots}

The stems can be woody, growing up to 72 inches in height, or a vine that can climb trees, walls and other structures, up to 150 feet in length. The stems are smooth and light brown to gray in color. Leaves are alternate and compound, consisting of three leaflets that vary greatly in shape (Figure 3 ). The leaves may be hairless and smooth or hairy and toothed on edge. Young leaves are often tinted with red, and the mature leaves change from dark green to red, orange, or yellow in the fall (Figure 4). The leaflets grow 2 to 6 inches long and 1 to 6 inches wide.

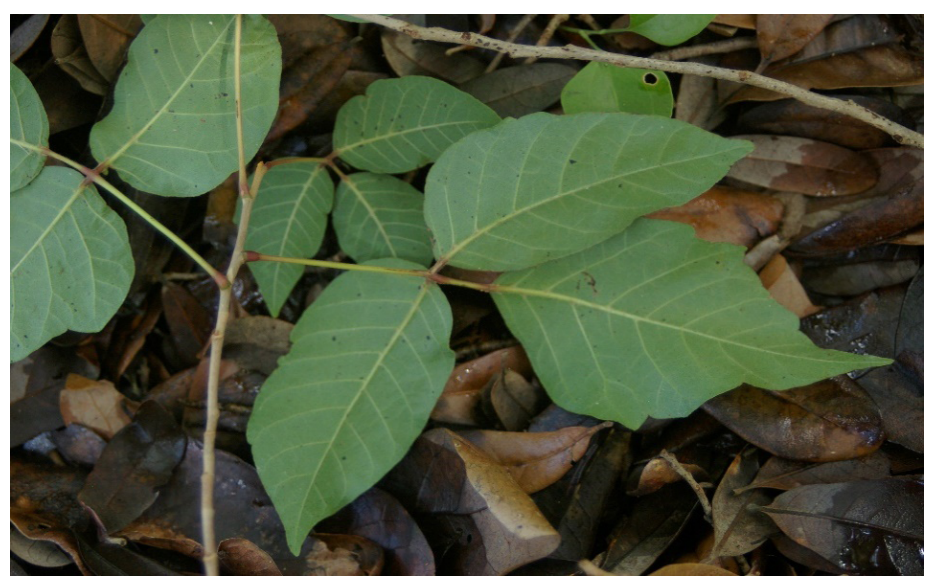

Figure 3. Three leaflets of poison ivy.

Credits: Annette Chandler, UF/IFAS

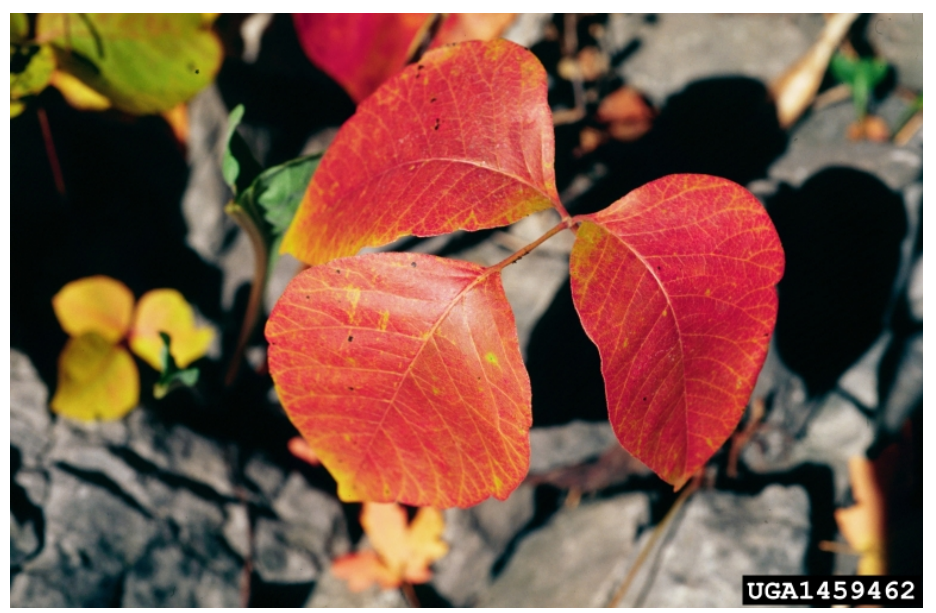

Figure 4. Poison ivy leaves during fall.

Credits: Steve Dewey, Utah State University, Bugwood.org

\section{Roots}

Poison ivy has a fibrous root system. The vines develop adventitious roots to climb and spread. The plant can also spread through rhizomes (underground stems) and root crowns.

\section{Inflorescence}

The flowers are formed in clusters on the stem that originate in the axis of the leaves along the sides of the smaller branches. The flowers are small and form a cluster of six or more. The flowers are yellowish green in color, round, and formed in a cluster 1 to 3 inches long (Figure 5). In Florida, poison ivy starts flowering from late March through September. 


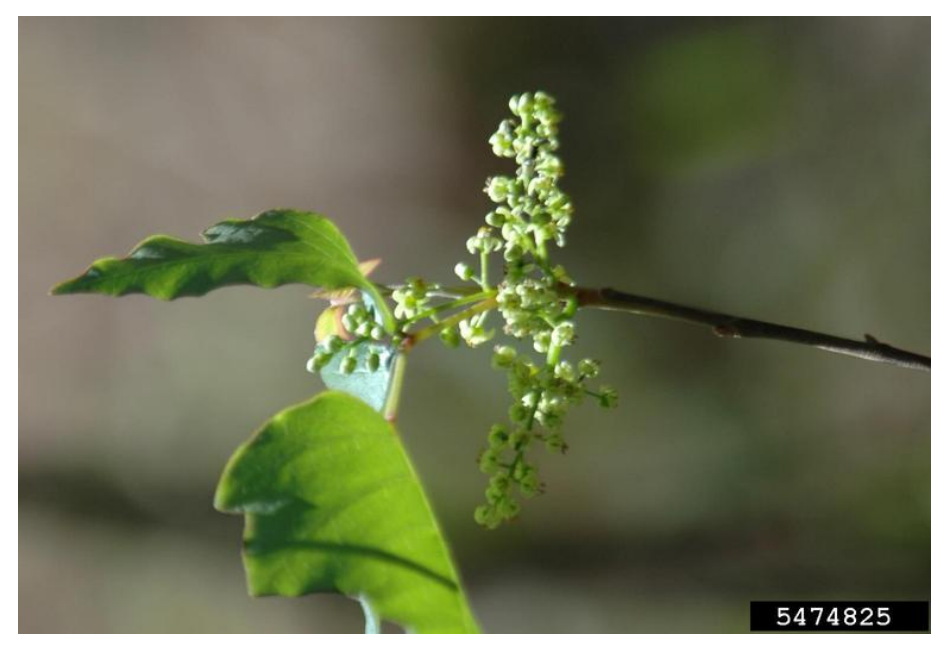

Figure 5. Poison ivy green-colored flowers.

Credits: Karan A. Rawlins, University of Georgia, Bugwood.org

\section{Fruits and Seeds}

The fruit grows in clusters on slender stems between the leaves and woody stem (Figure 6). The fruit is grayish white to yellow in color, round, and textured with a waxy coating (Brown 2015). Not all poison ivy plants produce fruits, because male and female flowers are on separate plants. The seeds are grayish in color and about $1 / 8$ inch in diameter. The fruits are a source of food for numerous birds and mammals, which digest the fleshy part and excrete the seeds. Seeds are commonly dispersed through birds, mammals, and water.

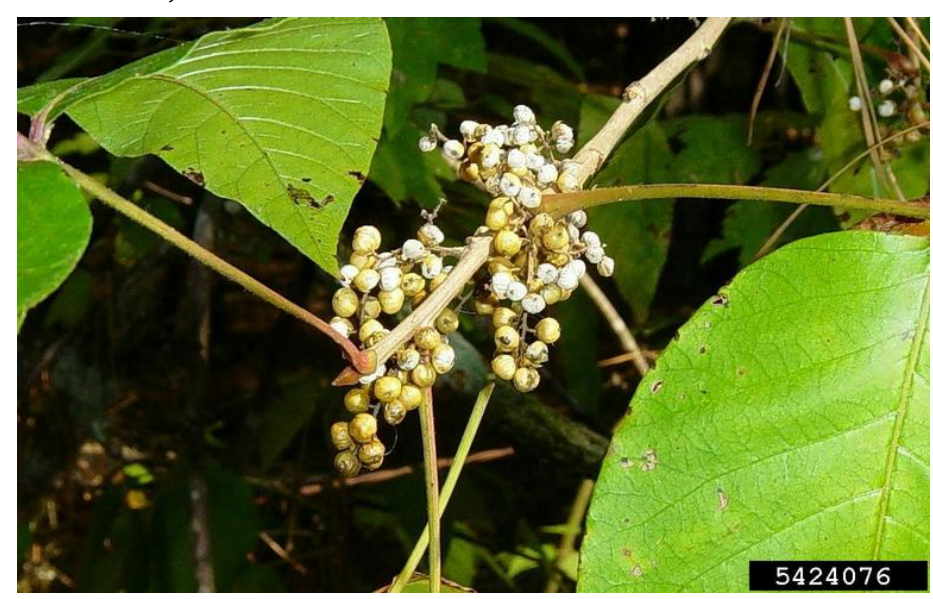

Figure 6. Poison ivy fruits.

Credits: Franklin Bonner, USFS (ret.), Bugwood.org

\section{Similar Species}

Poison ivy is commonly confused with Virginia creeper (Parthenocissus quinquefolia). Virginia creeper has 5 to 7 leaflets and toothed (serrated) margins distinguishing it from poison ivy (Figure 7). Other features that distinguish it from poison ivy are the blue-black berrylike fruit and the presence of tendrils used by the plant to attach to trees and other surfaces (Figure 8). The seedlings of box elder tree (Acer negundo) also look similar to poison ivy. Box elder seedlings often have three to five leaflets, but they can be distinguished by the placement of the leaves. The leaves in poison ivy are alternate, whereas box elder has opposite leaves (leaf stalk on the opposite side) (Hill and Tenney 2020). Box elder also lacks hairy aerial roots, and it does not produce any berries.

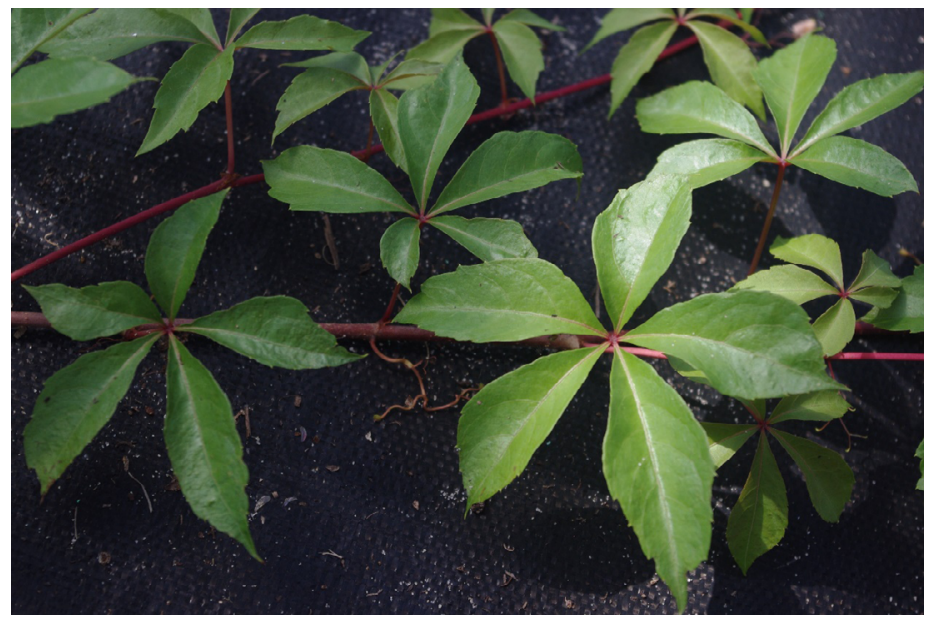

Figure 7. Virginia creeper leaves.

Credits: Annette Chandler, UF/IFAS

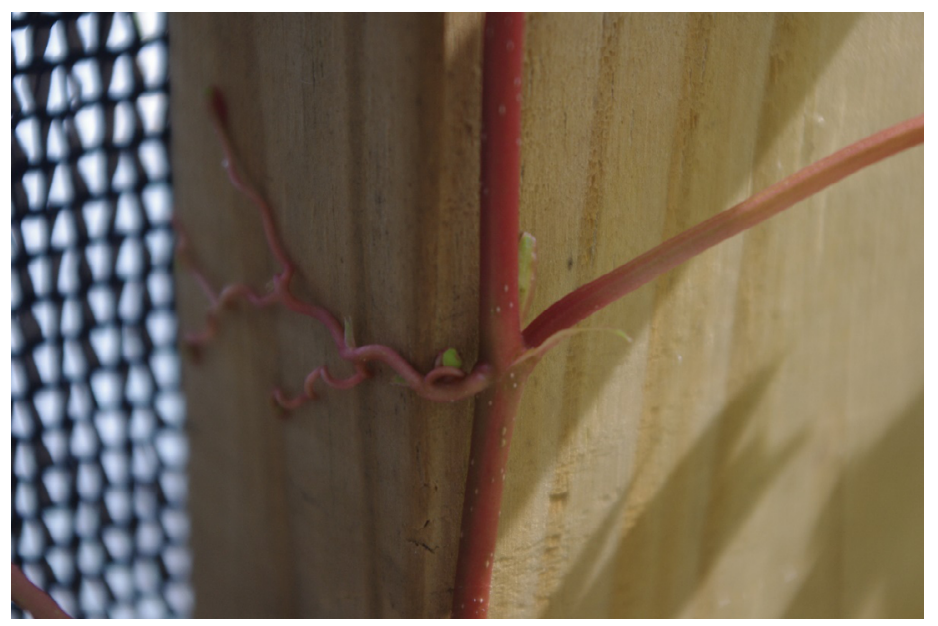

Figure 8. Virginia creeper stem and tendrils.

Credits: Annette Chandler, UF/IFAS

Other species related to poison ivy are poison oak (Toxicodendron diversilobum), poison sumac (Toxicodendron vernix) and Florida poisontree, all of which are native to Florida. Each contains the toxic oil responsible for poison ivy-like allergic reactions. Information on detailed identification of the following species can be found at https:// edis.ifas.ufl.edu/publication/EP220. Poison ivy relatives that grow in Florida such as mango (Mangifera indica) (https:// edis.ifas.ufl.edu/publication/MG216), cashew (Anacardium occidentale) (https://edis.ifas.ufl.edu/publication/HS377), and the highly invasive Brazilian peppertree (Schinus terebinthifolius) (https://edis.ifas.ufl.edu/publication/AA219) may also cause allergic reactions in some individuals. 


\section{Plant Biology}

Poison ivy can tolerate a wide range of soil conditions and has been observed growing in clay, silt, loam, and sandy soils (Brockway et al. 2009). The seeds germinate in midto-late spring in Florida and are viable for up to six years. Poison ivy can grow in both sunny and shaded locations but prefers shaded areas. Poison ivy contains an oily resin called urushiol, which causes skin rashes when people come in contact with it (Hill and Tenney 2020). Urushiol is present in all parts of the plants, including its aerial roots, dried leaves, and fruits. This allergic reaction can also occur indirectly if the oil has been in contact with an animal, tools, clothes, or shoes. The smoke from the burning poison ivy can cause lung irritation and nasal passages. The oil is toxic all year, but the severity of the allergic reaction varies depending on the time of year, condition of the plant, and individual sensitivity.

\section{Management}

\section{Physical and Cultural Control}

Small seedlings can be carefully pulled out with the use of gloves and protective clothing (long sleeves, long pants, etc.). If the plant is mature with a well-established root system, hand pulling will be very difficult if not impossible. Poison ivy can grow back from the fragments left in the ground. However, if the plant is small, removing the entire plant including roots and stems can be effective. Mechanical control such as regular mowing or tillage can be effective. Repeatedly cutting vines at the soil line can eventually provide control over several years.

\section{Chemical Control}

The most common herbicide used for poison ivy control in the landscape is glyphosate. It can be used as a directed spray around other plants at a $2 \%$ spray solution with water. If the vines are very large, it can be applied in combination with cutting the stems. To treat stems individually (such as those growing on other plants), the stem should be cut and can then be immediately treated ("painted") with a product that contains $41 \%$ glyphosate, either at full strength (no dilution) or diluted to a $50 \%$ mixture with water, following the label directions for cut-stump treatments.

Herbicides marketed as "poison ivy killer" are sold by many different manufacturers for homeowners and may contain different active ingredients, but these products commonly include some combination of glyphosate, triclopyr, 2,4-D, or dicamba. The homeowner products are typically readyto-use or sold at a low concentration of active ingredient. All of these herbicides can be effective, but they can also cause injury to other plants (especially broadleaf plants) if misapplied, so the user should use extreme caution. Herbicides that contain triclopyr, 2,4-D, or dicamba are not labeled for use in landscape planting beds. In this situation, glyphosate can be used in addition to many other nonselective glyphosate alternatives. Nonselective alternatives such as glufosinate (Finale), diquat (Reward), and pelargonic acid (Scythe) can work on small plants and will defoliate large plants, but because they are not translocated, they are typically ineffective at completely eliminating large established poison ivy plants. For more information on glyphosate alternatives, refer to Use of Glyphosate and Herbicide Alternatives for Weed Control in Florida Landscape Planting Beds.

\section{References}

Brown, S. P. 2015. Identification of Poison Ivy, Poison Oak, Poison Sumac, and Poisonwood. ENH886. Gainesville: University of Florida Institute of Food and Agricultural Sciences. Accessed 5 May 2020. https://edis.ifas.ufl.edu/ publication/EP220

Brockway, D. G., K. W. Outcalt, B. L. Estes, and R. B. Rummer. 2009. "Vegetation Response to Midstorey Mulching and Prescribed Burning for Wildfire Hazard Reduction and Longleaf Pine (Pinus palustris Mill.) Ecosystem Restoration." Forestry 82 (3): 299-314. https://doi.org/10.1093/ forestry/cpp010

Hill, E., and A. Tenney. 2020. Poison Ivy in Michigan. Michigan State University Extension Bulletin E3438. https://www.canr.msu.edu/pestid/resources/plant-andweed-identification/PoisonIvy_E3438_AA\%20(002).pdf

USDA-NRCS. 2019. Toxicodendron radicans (Poison ivy). https://plants.usda.gov/core/profile?symbol=TORA2

Wunderlin, R. P., B. F. Hansen, A. R. Franck, and F. B. Essig. 2019. "Atlas of Florida Plants." Accessed May 4, 2020. https://florida.plantatlas.usf.edu/Plant.aspx?id=3476 